\title{
Airtraq in difficult/ failed intubation
}

\author{
*HM Krishna ${ }^{I}$, N Shetty ${ }^{2}, V_{\text {Vinodhadevi }}{ }^{3}$ \\ Associate Professor ${ }^{1,2}$, Resident ${ }^{3}$, Department of Anaesthesiology, Kasturba Medical College, \\ Manipal University, Manipal, India
}

*Corresponding author: hmkrishna20032002@gmail.com

\begin{abstract}
Background:
Airtraq has been described for the management of difficult airway. It is not clear from the literature about the utility of Airtraq in situations of failed intubation as a rescue device. This study was conducted to evaluate the utility of Airtraq as a rescue device during difficult/ failed intubation.
\end{abstract}

\section{Methods:}

This retrospective study was conducted by analysing the anaesthetic data of patients who had failed/difficult intubation to evaluate the utility of Airtraq in such situations. Patient characteristics, predictors of difficult airway, glottic view with Macintosh laryngoscope and Airtraq, number of intubation attempts and use of intubation aides were analysed.

\section{Results:}

During the study period of one year fourteen patients had difficult/failed intubation with Macintosh laryngoscope and Airtraq was used as an alternative rescue airway device in these patients. Intubation was successful in all the patients. Cormack and Lehane grade of the glottis view improved by 1 to 3 grades with Airtraq. Restricted neck extension and modified Mallampati class 3 or 4 were the difficult airway predictors observed in these patients where Airtraq was found to be useful.

\section{Conclusions:}

Airtraq has a definite role as a rescue airway device when intubation fails with or is difficult with Macintosh laryngoscope.

Key words: Airtraq, difficult intubation, failed intubation, direct laryngoscopy

\section{Introduction}

Airtraq [Prodol Meditec S.A., Las Arenas (Vizcaya), Spain] is an indirect laryngoscope that has been developed to facilitate tracheal intubation. There are case reports and few studies describing the utility of Airtraq in difficult airway situations. ${ }^{1-5}$ The utility of Airtraq as a backup device for intubation in the event of failure/ difficulty with conventional laryngoscope is not clear. In this retrospective study we analysed the data of patients who had difficult/ failed intubation with conventional laryngoscope and in whom Airtraq was used as an alternate technique for intubation.

\section{Materials and Methods}

After obtaining approval from the Hospital Ethics Committee, this retrospective study was conducted with the data procured from the department of anaesthesia data base. Data of patients who had difficult/failed intubation and in whom Airtraq was used as an alternative following the use of direct laryngoscope during the period August 2010 to August 2011 were considered. Inclusion criteria were (a) patients of either gender who had difficult/failed intubation with conventional direct laryngoscopy and in whom Airtraq was used for intubation (b) one of the authors were primarily responsible for the anaesthetic management of such case or were called for help to intubate. After retrieval of data, patients were identified only by serial numbers and the anonymity was maintained. Individual consent of the patients for data analysis and publication was waived off. The data retrieved comprised of patient characteristics, identified predictors of difficult airway, technique of anaesthetic induction (intravenous or inhalational) and the use of 
muscle relaxants to facilitate tracheal intubation, direct laryngoscopic view of glottis as graded by Cormack and Lehane classification with/without OELM (optimal external laryngeal manipulation), number of intubation attempts with direct laryngoscope, whether stylette or bougie was used to aid intubation, the experience of the anaesthesiologist performing laryngoscopy during each attempt, glottic view obtained with Airtraq (applying Cormack and Lehane classification), whether with or without OELM, number of intubation attempts with Airtraq, if intubation failed with Airtraq the method by which airway was managed, adverse events if any. ${ }^{6}$

With this data we aimed to (a) find out the success rate of intubation with Airtraq when intubation with conventional direct laryngoscopy was difficult or failed (b) identify the airway assessment predictors which predicted difficult intubation and whether Airtraq would be useful in their presence.

\section{Results}

During the study period fourteen patients had difficult/failed intubation (Table 1). All were adults except for two paediatric patients (patient numbers 5 and 9). Difficult airway was not anticipated in patient numbers 2, 4 and 9; only retrospectively the predictors of difficult airway were identified. In all other patients difficult airway was anticipated and appropriate preparations to manage had been made. The extent of difficulty in these cases was not estimated to be so severe as to require an awake intubation. Patient number 5 was diagnosed to have Hallermann-Streiff syndrome; so muscle relaxant was avoided and intubation was done with the patient spontaneously breathing under sevoflurane anaesthesia. In all other cases either succinyl choline or vecuronium was used (after confirming ease of mask ventilation) to facilitate tracheal intubation.

Glottic view with direct laryngoscopy (Macintosh laryngoscope) was grade III or IV in all the cases with OELM. This view improved by one to three grades with the use of Airtraq. Intubation attempts with direct laryngoscopy before resorting to Airtraq ranged from one to four attempts. Stylette was used to facilitate intubation using Macintosh laryngoscope when the number of attempts exceeded one.

Intubation was successful with Airtraq in all the cases. In all but one case (patient number 7) intubation was successful in first attempt with Airtraq. In patient number 7 where intubation was successful after two attempts with Airtraq, the glottic view during first attempt (by resident anaesthesiologist) was grade II and resulted in oesophageal intubation. The second attempt (by consultant anaesthesiologist) provided grade I glottic view with OELM and intubation was successful. OELM was used with Airtraq in patient numbers 2, 6 and 7. Only in patient number 8 fiberoptic bronchoscopy was tried for intubation following failure to intubate with conventional laryngoscopy. Intubation failed with fiberoptic bronchoscopy due to poor view ('red out' view despite oropharyngeal suctioning) and subsequent intubation with the use of Airtraq was successful.

Restricted neck extension and modified Mallampati class (MMP) 3 or 4 were the predictors of difficult airway consistently seen in most of the cases. In addition to these, other predictors of difficult airway observed were thyromental distance (TMD) $<6 \mathrm{~cm}$ (in adult patients), retrognathia, receding mandible and irregular dentition.

Table 1: Patient characteristics, predictors of difficult airway and glottic view obtained

\begin{tabular}{|c|c|c|c|c|c|c|c|c|}
\hline \multirow{2}{*}{$\begin{array}{l}\mathrm{Ca} \\
\text { se } \\
\text { no. }\end{array}$} & \multirow{2}{*}{$\begin{array}{l}\text { Age } \\
\text { (yea } \\
\text { rs) }\end{array}$} & \multirow{2}{*}{$\begin{array}{l}\mathrm{S} \\
\mathrm{e} \\
\mathrm{x}\end{array}$} & \multirow{2}{*}{$\begin{array}{l}\text { W } \\
\text { ei } \\
\text { gh } \\
\text { t } \\
\text { (k } \\
\text { g) }\end{array}$} & \multirow[t]{2}{*}{$\begin{array}{l}\text { Predictors of } \\
\text { difficult airway }\end{array}$} & \multicolumn{2}{|c|}{$\begin{array}{l}\text { With Macintosh } \\
\text { laryngoscope }\end{array}$} & \multicolumn{2}{|c|}{ With Airtraq } \\
\hline & & & & & $\begin{array}{l}\text { Glot } \\
\text { tic } \\
\text { view }\end{array}$ & $\begin{array}{l}\text { Intubati } \\
\text { on } \\
\text { attempt } \\
\text { s }\end{array}$ & $\begin{array}{l}\text { Glo } \\
\text { ttic } \\
\text { vie } \\
\text { w }\end{array}$ & $\begin{array}{l}\text { Intub } \\
\text { ation } \\
\text { atte } \\
\text { mpts }\end{array}$ \\
\hline 1 & 70 & $M$ & 80 & $\begin{array}{l}\text { Acromegaly } \\
\text { Limited neck } \\
\text { extension, MMP } 3\end{array}$ & III & 1 & l & 1 \\
\hline 2 & 33 & M & 70 & $\begin{array}{l}\text { Limited neck } \\
\text { extension, MMP } \\
4, \text { TMD } 4 \mathrm{~cm}\end{array}$ & III & 4 & II & 1 \\
\hline 3 & 55 & M & 68 & $\begin{array}{ll}\text { Limited } & \text { neck } \\
\text { extension, MMP } \\
4, \quad \text { TMD } 4 \mathrm{~cm} \text {, } \\
\text { short neck }\end{array}$ & III & 1 & II & 1 \\
\hline 4 & 52 & M & 60 & $\begin{array}{lr}\text { Limited } & \text { neck } \\
\text { extension, MMP } \\
3, \quad \text { irregular } \\
\text { dentition }\end{array}$ & III & 3 & $\|$ & 1 \\
\hline 5 & $9 / 12$ & $\mathrm{~F}$ & $\begin{array}{l}7 . \\
2\end{array}$ & $\begin{array}{l}\text { Double chin, } \\
\text { retrognathia, }\end{array}$ & III & 1 & $\|$ & 1 \\
\hline 6 & 48 & M & 54 & $\begin{array}{l}\text { Receding } \\
\text { mandible, MMP } 4\end{array}$ & IIII & 1 & I & 1 \\
\hline 7 & 60 & M & 90 & $\begin{array}{l}\text { Limited neck } \\
\text { extension, MMP } \\
\text { 3, Heavy jaw, } \\
\text { missing incisors }\end{array}$ & III & 1 & 1 & 2 \\
\hline 8 & 24 & M & 60 & $\begin{array}{l}\text { Retrognathia, } \\
\text { MMP } 3\end{array}$ & IV & 1 & I & 1 \\
\hline 9 & 12 & $M$ & 35 & $\begin{array}{l}\text { Limited neck } \\
\text { extension, MMP } 3\end{array}$ & IV & 2 & I & 1 \\
\hline 10 & 35 & $M$ & 55 & $\begin{array}{l}\text { Retrognathia, } \\
\text { MMP } 3\end{array}$ & III & 2 & 1 & 1 \\
\hline 11 & 59 & $M$ & 90 & $\begin{array}{l}\text { Limited neck } \\
\text { extension, MMP } 4\end{array}$ & III & 2 & I & 1 \\
\hline 12 & 35 & $M$ & 65 & $\begin{array}{l}\text { Retrognaathia, } \\
\text { MMP } 3\end{array}$ & III & 2 & I & 1 \\
\hline 13 & 59 & $M$ & 90 & $\begin{array}{l}\text { Limited neck } \\
\text { extension, MMP } 4\end{array}$ & III & 2 & I & 1 \\
\hline 14 & 65 & $M$ & 80 & $\begin{array}{l}\text { Limited neck } \\
\text { extension } \\
\text { (ankylosis), } \\
4\end{array}$ & III & 2 & I & 1 \\
\hline
\end{tabular}


MMP-Modified Mallampati class, TMDThyromental distance, M-Male, F-Female

\section{Discussion}

Tracheal intubation was successful in all the patients in whom intubation was difficult or failed with direct laryngoscope (Macintosh laryngoscope). Limited neck extension and modified Mallampati class 3 or 4 were the consistently observed difficult airway parameters when Airtraq was found to be useful. The Airtraq blade consists of two adjacent channels, one through which a tracheal tube can be passed and the other that contains a series of lenses, prisms and mirrors to transfer the image from the illuminated tip to a proximal view finder. The exaggerated curvature of the blade and internal arrangement of optical components provide a view of the glottis without the alignment of the oral, pharyngeal and laryngeal axes. Difficult laryngoscopy and intubation in patients with difficult airway are primarily because of the difficulty in aligning these three axes. In such situations, it is difficult to visualize the larynx using the conventional laryngoscope. Airtraq offers a theoretical advantage in anticipated difficult laryngoscopy, in better glottic visualisation, as it is designed to provide the glottic view without alignment of the three axes.

Studies have evaluated Airtraq in simulated difficult intubation situations. ${ }^{1,2}$ There are a few case reports describing the utility of Airtraq in difficult intubation due to various causes. ${ }^{7,8}$ Whether Airtraq can be relied upon as a backup alternative device in a situation of failed/difficult intubation is not clear apart from the description in a prospective case series. ${ }^{9}$ Modified Mallampati class 3 or 4 and reduced thyromental distance were the predictors of difficult airway observed in that case series. There is no mention whether any of the patients had limited neck extension. Airtraq has been evaluated in comparison with Macintosh laryngoscope in patients at increased risk for difficult intubation. ${ }^{4}$ Patients with thyromental distance $<6 \mathrm{~cm}$, Mallampati class 3 or 4 , inter incisor distance $<$ $4 \mathrm{~cm}$ and previously documented difficult intubation were included. Limited or restricted neck extension was not listed in the inclusion criteria. ${ }^{4}$ Our series had patients of different age groups and even unanticipated difficult airway. Difficult airway is predicted by the combination of different airway parameters assessed preoperatively. Often, the presence of only one predictor of difficult airway like modified Mallampati class 3 or 4 or limited neck extension are ignored when all other airway parameters are normal. This was the case with patient numbers 2, 4 and 9 in whom airway was not predicted to be difficult from the combination of airway parameters.

Being a retrospective study we had some limitations. The term 'difficult/failed intubation' has been used in this study which does not adhere to the standard definitions of difficult intubation or failed intubation. In real life situations these definitions are not strictly adhered to before proceeding with an alternative airway device. We had no choice of standardising these. The authors who used Airtraq were experienced with the use of the device. It cannot be speculated that the success rate with Airtraq would remain as high in the hands of novices. Bougie was not used and a stylette was used in all the cases when the number of attempts exceeded one. This was purely based on preference and comfort of the laryngoscopist. Neck extension was documented as 'limited' or 'restricted' and not objectively measured with goniometer. So the extent of restriction in neck extension is not known.

Further studies are required to analyse the cause for failure to intubate with Airtraq and thereby identify the predictors in presence of which Airtraq may not be useful.

We conclude that Airtraq can be a useful alternative device in difficult/failed intubation with conventional laryngoscopy, particularly in patients with limited neck extension and modified Mallampati class 3 or 4 airway.

\section{References}

1. Woollard M, Lighton D, Mannion W, Watt J, McCrea C, Johns I, et al. Airtraq vs standard laryngoscopy by student paramedics and experienced prehospital laryngoscopists managing a model of difficult intubation. Anaesthesia 2008;63:26-31

http://dx.doi.org/10.1111/j.13652044.2007.05263.x

PMid: 18086067

2. McElwain J, Malik MA, Harte BH, Flynn NM, Laffey JG. Comparison of the C-MAC $®$ video laryngoscope with the Macintosh, 
Glidescope ${ }^{\circledR}$, and Airtraq ${ }^{\circledR}$ laryngoscopes in easy and difficult laryngoscopy scenarios in manikins. Anaesthesia 2010;65:483-9

http://dx.doi.org/10.1111/j.1365-

2044.2010.06307.x

PMid:20337620

3. Lange M, Frommer M, Redel A, Trautner H, Hampel J, Kranke P, et al. Comparison of the Glidescope and Airtraq optical laryngoscopes in patients undergoing direct microlaryngoscopy. Anaesthesia 2009;64:323-8

http://dx.doi.org/10.1111/j.13652044.2008.05781.x

PMid:19302649

4. Maharaj CH, Costello JF, Harte BH, Laffey JG. Evaluation of the Airtraq and Macintosh laryngoscopes in patients at increased risk for difficult tracheal intubation. Anaesthesia 2008;63:182-8

http://dx.doi.org/10.1111/j.1365-

2044.2007.05316.x

PMid:18211450

5. Maharaj CH, Buckley E, Harte BH, Laffey

JG. Endotracheal intubation in patients with cervical spine immobilization: A comparison of Macintosh and AirtraqTMlaryngoscopes.

Anesthesiology 2007;107:53-9

http://dx.doi.org/10.1097/01.anes.0000267529.7

1756.f0

PMid:17585215

6. Cormack RS, Lehane J. Difficult tracheal intubation in obstetrics. Anaesthesia 1984;39:1105-11

http://dx.doi.org/10.1111/j.1365- 2044.1984.tb08932.x

PMid:6507827

7. Dhonneur G, Ndoko S, Amathieu R, Housseini LE, Poncelet C, Tual L. Tracheal intubation using the Airtraq ${ }^{\circledR}$ in morbid obese patients undergoing emergency cesarean delivery. Anesthesiology 2007;106:629-30 http://dx.doi.org/10.1097/00000542200703000-00027

PMid:17325521

8. Norman A, Date A. Use of the Airtraq ${ }^{\circledR}$ laryngoscope for anticipated difficult laryngoscopy: Anaesthesia 2007;62:533-4 http://dx.doi.org/10.1111/j.1365-

2044.2007.05075_12.x

PMid:17448079

9. Maharaj CH, Costello JF, McDonnell JG, Harte BH, Laffey JG. The Airtraq as a rescue airway device following failed direct laryngoscopy: a case series. Anaesthesia 2007;62:598-601

http://dx.doi.org/10.1111/j.1365-

2044.2007.05036.x

PMid:17506739 